\title{
Type specimens preserved in the Trèmols and Costa herbaria (BC)
}

\author{
${\text { Laura Gavioli }{ }^{1 *} \text {, Neus Ibáñez }{ }^{1} \& \text { Ignasi Soriano }}^{2}$ \\ ${ }^{1}$ Instituto Botánico de Barcelona (IBB-CSIC-ICUB), Passeig del Migdia s.n., E-08038 Barcelona, Spain; lgavioli.bcn@gmail.com \\ ${ }^{2}$ Departamento de Biología Vegetal (Botánica), Universidad de Barcelona, Av. Diagonal, 643, E-08028 Barcelona, Spain \\ Recibido: 15-IV-2015; Aceptado: 23-XII-2015; Publicado on line: 9-XII-2016
}

\begin{abstract}
Gavioli, L., Ibáñez, N. \& Soriano, I. 2016. Type specimens preserved in the Trèmols and Costa herbaria (BC). Anales Jard. Bot. Madrid 73(2): e041.

The Trèmols herbarium, preserved at the Botanical Institute of Barcelona, is one of the oldest herbaria in Catalonia, largely made up of European plants collected in $19^{\text {th }}$ century. The digitization of this historical collection, currently in progress, has made possible to locate nomenclatural types of various authors, acquired through exchange. In this article, we indicate two syntypes (for Fumaria caespitosa Loscos and Carex loscosii Lange), and one isolectotype (Polygala vayredae Costa) in Trèmols herbarium. Additionally, we designate the lectotype of Polygala vayredae in the Costa herbarium and its isolectotype in the Vayreda herbarium.

Keywords: Botanical Institute of Barcelona, Carex loscosii, Fumaria caespitosa, Polygala vayredae, Trèmols and Costa herbaria, type specimens.
\end{abstract}

\section{Resumen}

Gavioli, L., Ibáñez, N. \& Soriano, I. 2016. Especímenes tipo conservados en los herbarios de Trèmols y Costa (BC). Anales Jard. Bot. Madrid 73(2): e041.

El herbario Trèmols, conservado en el Instituto Botánico de Barcelona, es uno de los primeros herbarios en Cataluña, compuesto en gran parte por plantas europeas recolectadas durante el siglo XIX. La digitalización de esta colección histórica, actualmente en curso, ha permitido localizar tipos nomenclaturales de diversos autores, adquiridos mediante intercambio. En este artículo, indicamos dos sintipos (para Fumaria caespitosa Loscos y Carex loscosii Lange) y un isolectotipo (Polygala vayredae Costa) en el herbario Trèmols. De manera adicional, designamos el lectotipo de Polygala vayredae en el herbario Costa y su isolectotipo en el herbario Vayreda.

Palabras clave: Carex loscosii, Fumaria caespitosa, herbarios Trèmols y Costa, Instituto Botánico de Barcelona, Polygala vayredae, tipos nomenclaturales.

Copyright: @ 2016 CSIC. This is an open-access article distributed under the terms of the Creative Commons Attribution (CC-by) Spain 3.0 License.

\section{INTRODUCTION}

The Trèmols herbarium, kept at the Botanical Institute of Barcelona, is one of the first herbaria in Catalonia, largely made up of European plants (Gavioli \& al., 2013a, 2013b). The current F. Trèmols' collection consists of approximately 9,000 specimen sheets, arranged in 60 volumes, plus four boxes of Hieracium spp. and 85 boxes with additional material. A computerized inventory at the genus level for all volumes, the original catalogue of the herbarium, and taxonomical cards are now available. We have also developed a preliminary list on the contents of the 85 extra boxes (Gavioli \& al., 2013a, 2013b).

At present, 3,695 specimens of Trèmols herbarium have been computerized, corresponding to 22 full volumes and 4 boxes of Hieracium. For the most part, these sheets derive from botanical exchanges $(2,480 ; 67.1 \%)$, as a result of Trèmols involvement in botanical societies such as the Société Botanique de France, the Société Helvétique pour l'Échange des Plantes (from 1870), and the Sociedad Botánica Barcelonesa (1872-1878). Only 1,215 sheets were collected by Trèmols $(32.9 \%)$, most of them in Catalonia $(1,063$; $87.5 \%$ ).

The aims of this study are focused on find and designate types in the computerized part of Trèmols herbarium (BC). This search has also lead us to look into other contemporary collections from 19th century, particularly in Costa and Vayreda herbarium (BC).

\section{MATERIAL AND METHODS}

We computerized the sheets from Trèmols herbarium with the Herbar program (Pando \& al., 1994-2010).

Records include all information available on every sheet, such as taxon name and author, collector, locality, and date. Additionally, we brought up-to-date locality data and nomenclature and, in some cases, identifications were also revised.

During this process, we have detected several putative type specimens among the exchanged materials. In these cases, research also included the protologue of taxa, and information about the process of typification. In some cases, the search for types was expanded to other historical herbaria of Botanical Institute of Barcelona of botanists involved in exchanges with $\mathrm{F}$. Trèmols, for instance, A.C. Costa, and E. Vayreda the author and the collector of the original materials of Polygala vayredae.

\section{RESULTS}

Among the plant material preserved in the $\mathrm{BC}$-Trèmols, BC-Costa herbaria, we designate below two syntypes and one lectotype. For all taxa, we indicate: name; place of publication and taxon's author; indication of the original locality in the protologue; locality of the type in brackets; a transcription of the original label; the date of gathering, the label's author in cursive ( $\mathrm{m}=$ manuscript); herbarium number and 
some remarks on the typification process, or on nomenclatural or geographical matters.

Fumaria caespitosa Loscos, Tratado Pl. Aragón: 26 (1876-1877)

Ind. loc.: "Leg. circumcirca Castelserás in segetes sicci vel paulo irrigati, speciatim ultra La Nora freq. 28 Apr. 1875, Loscos."

TYPE: [Spain. Teruel. Castelserás, La Nora:] "[20]/ SERIES EXSICCATA FLORAE ARAGONENSIS: / CENTURIA PRIMA. / N. 2. Fumaria (cespitosa) Loscos mser. / Leg. circumcirca Castelserás in segetes sicci vel paulo / irrigati, speciatim ultra La Nora freq. 28 Apr. 1875 / Loscos. / F. Cespitosa proxima F. Parviflorae quacum confusa in Serie Inconfecta / n. 90: ab ea distinguitur floribus omnino purpurascentibus, petalo su/ periore apice emarginato; inferiore abrupte in lamina suborbiculari su- / perne dilatato. Folia glauco-cinerea laciniis subelliptici subplanis: caules / in solo pingui intricatissimi, cespitosi.", 28 Apr 1875, F. Loscos s.n. (syntype: BC-Trèmols 865594!, fig. 1; former syntypes: BC 97570!, JE 00018039!, SG 2737!).

Remarks.-Lidén (1986: 465) considers this name a taxonomic synonym of $F$. vaillantii Loisel. in J. Bot. (Desvaux) 2: 358 (1809).

Carex loscosii Lange, Vidensk. Meddel. Naturhist. Foren. Kjøbenhavn 1877-1878: 223 (1878)

Ind. loc.: "Circa Castelserás Aragoniae ad ripas corrugi "la acequia nueva" vocati parcius 19 Jun. c. fl. matur. Loscos!”

TYPE: [Spain. Teruel. Castelserás, La Acequia nueva:] "Herb. Joh. Lange / SERIES EXSICCATA FLORAE ARAGONENSIS: / CENTURIA PRIMA. / N. 92. Carex Mairii Coss. var. Serie imp. pag. / 428 lin. 9. / Leg. pr. Castelserás ad ripas corrugi vocati La Ace- / quia nueva, sed partius, 19 Jun. 1875 / Loscos. / Spiculis femineis erectus, ovoideis: utriculis patentibus glabris, faciebus / convexis obscure nervosis: foliis asperis: caulibus obscure trigonis, levibus, / apice asperis / Loscosii Lge (m. Loscos).", 19 Jun 1875, F. Loscos s.n. (syntype: BC-Trèmols 876826!; former syntypes: BC-Trèmols 876827!, fig. 2; BC-Trèmols 876828!; BC-Trèmols 876829 !).

Remarks.-The printed label suggests that F. Loscos determined the plant as C. mairii Coss. (Loscos, 1876-1877: 44-45) but with some doubts (he wrote "var." in the label), so he sent a sample to J.M.C. Lange in 1878 for confirmation (Muñoz Garmendia \& González Bueno, 2001). Lange regarded it as a new species, publishing, and dedicating it to Loscos (Lange, 1878). However, Luceño (2008: 189) considers this name a taxonomic synonym of C. mairii Coss. \& Germ.

Polygala vayredae Costa, Supl. Cat. Pl. Cataluña 10: 91 (1877) Ind. loc.: "Hab. In collibus Vall del Bach inter Capsech et Baget (Olot) sitis die 23. ${ }^{a}$ Aprilis hujusce anni amiciss. Stanislaus Vayreda detexit et mecum benevole communicavit."

TYPE: [Spain. Catalonia. Olot, Vall del Bach entre Capsech i Baget:] "Herbarium A. C. Costae. / Polygala (Chamaebuxus?) Vayredae / n. sp. Suplem. Fl. Cat. p. / Amicissumus Stan. Vayreda Fl. nostra observatori / felicissimo libenter dicavi. / Hab. in collibus ditioris Olot in loco dicto / Vall del Bach inter Capsech et Baget / Legit die 23 Aprilis anni 1877 c. fl. cl. Vayreda”, 23 Apr 1877, A.C. Costa s.n. (m. Costa) (lectotype, here designated: BC-Costa 929697!, fig. 3; isolectotypes: BC-Vayreda 929698!, BC-Trèmols 918953!).

Remarks.-Species endemic to the eastern Pyrenees and only known in a few localities in La Garrotxa district (Sáez \& al., 2010: 244). F.X. de Bolòs was the first collector of this plant, and identified it as Polygala bracteolata L. (?) conferatur cum chamaebuxo (Bolòs, 1927). In April 1877, Vayreda retrieved the plant and sent some specimens to Costa, who described the species as a new taxon in May (Costa, 1877). Later, Vayreda distributed other specimens, apparently of the same collection, through the Societé Helvétique.

\section{DISCUSSION}

The analysis of the 3,695 specimens from the Trèmols Herbarium clearly shows the importance of the materials exchanged by this lay botanist (Gavioli \& al., 2013a, 2013b). Thanks to these exchanges, we detected several types in BC-Trèmols and other coetaneous herbaria.

Trèmols did not described any taxa, so it is not surprising that the types detected so far correspond to specimens obtained by exchange: Fumaria caespitosa Loscos and Carex loscosii Lange belong to "Series Exsiccata Florae Aragonensis" distributed by F. Loscos and Polygala vayredae was sent by E. Vayreda. It should be added that in recent floras like Flora iberica, Fumaria caespitosa and Carex loscosii are treated as taxonomic synonyms of other species. On the other hand, the endemic taxon Polygala vayredae Costa, dedicated precisely to its collector, is accepted as species. For this taxon, in addition, we have proposed the lectotype conserved in Costa herbarium (the only specimen studied with handwritten label). The computerization of the rest of the herbarium Trèmols should allow us to detect other types, in particular from the exsiccata distributed by Loscos, who described dozens of taxa from Aragon in the second half of the 19th century.

Beyond these type specimens, the great value of this collection is, undoubtedly, the fact that the Trèmols herbarium is one of the first herbaria in Catalonia constituted largely of European plants.

With our work we want to highlight the importance of the Trèmols herbarium, not only as the core foundation of the General herbarium of the IBB, but also as a place for collecting samples of the leading botanists of the second half of 19 th century. 


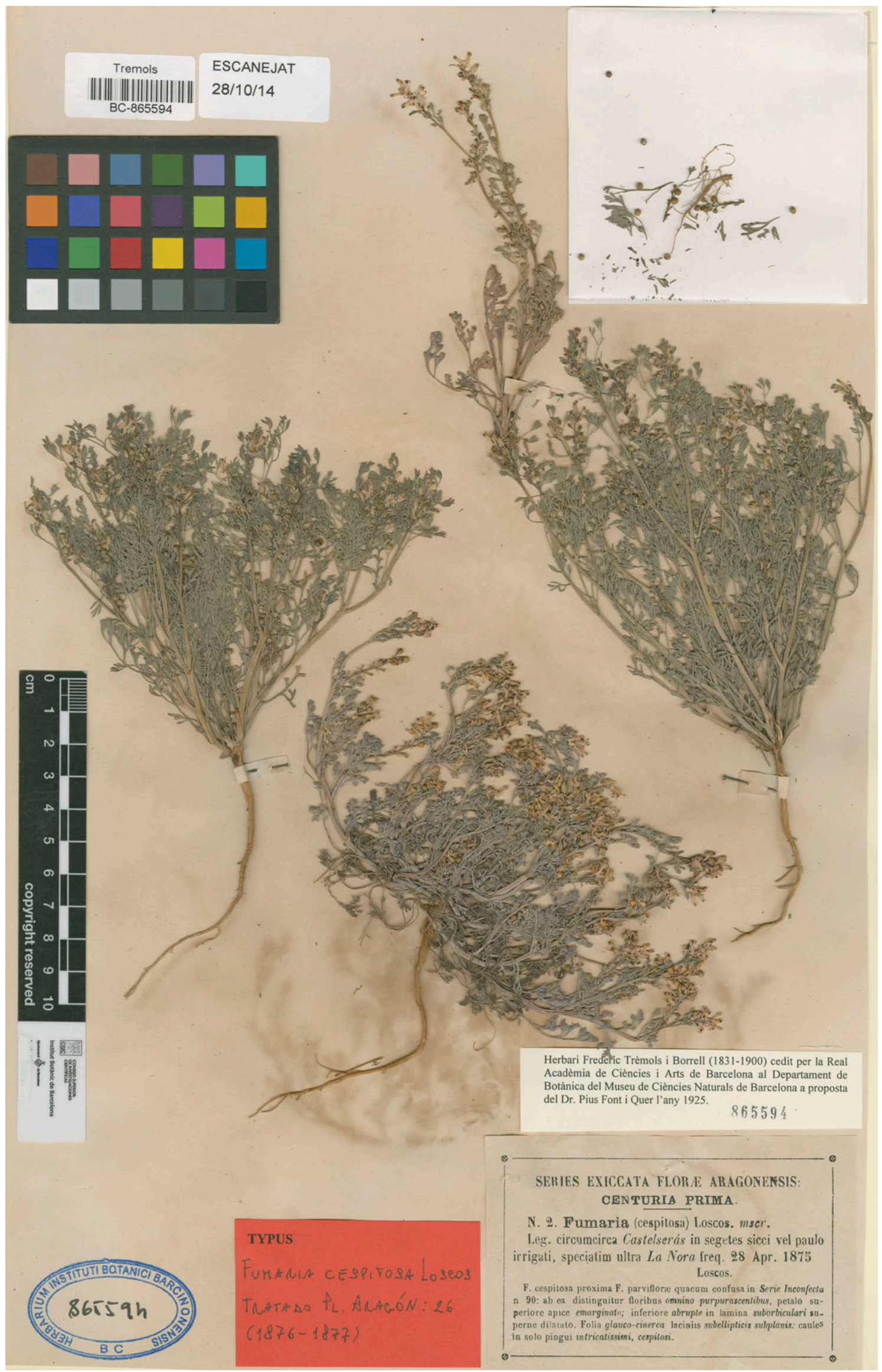

Fig. 1. Syntype of Fumaria caespitosa Loscos (BC-Trèmols 865594). 


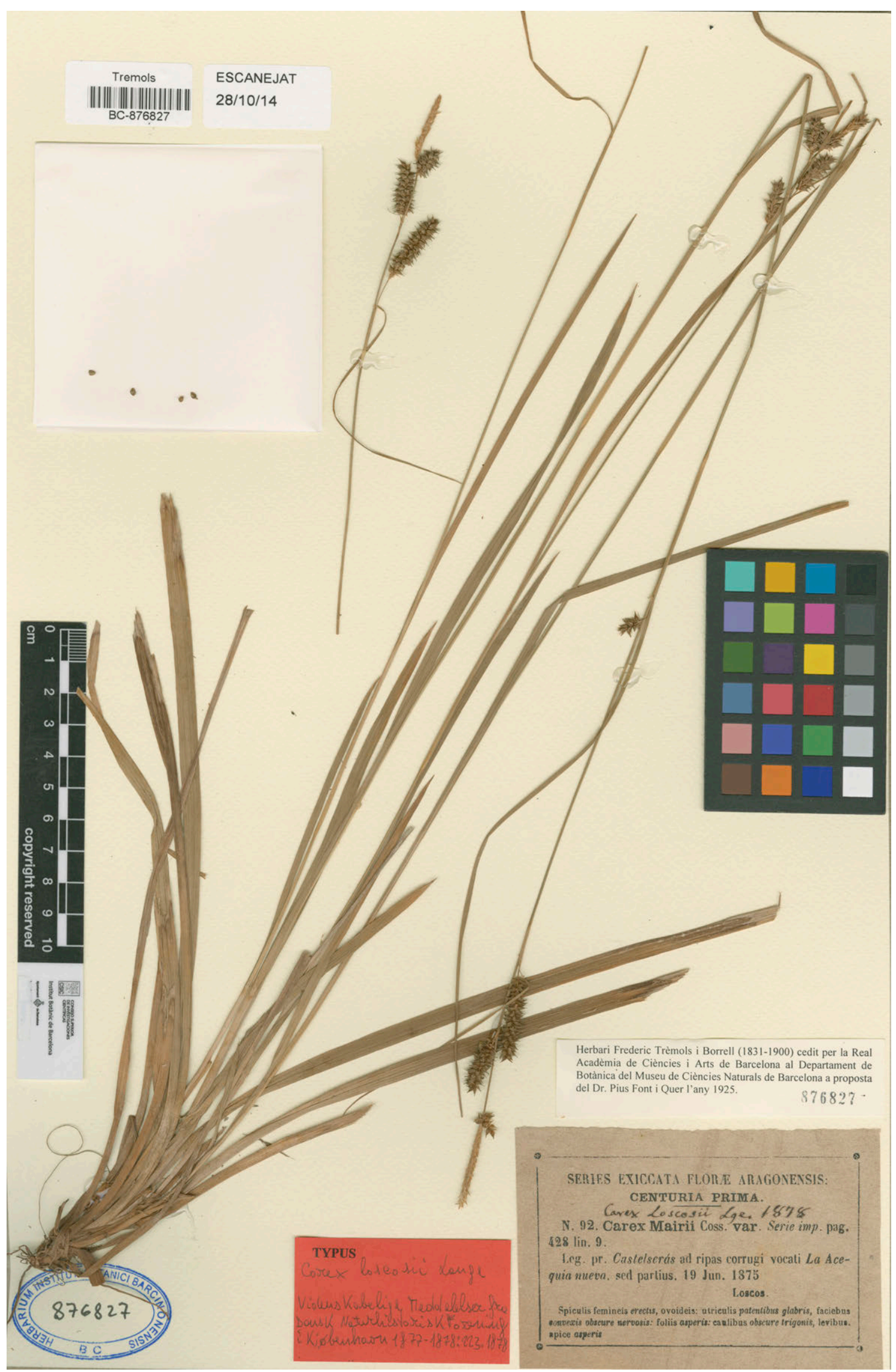

Fig. 2. Syntype of Carex loscosii Lange (BC-Trèmols 876827). 


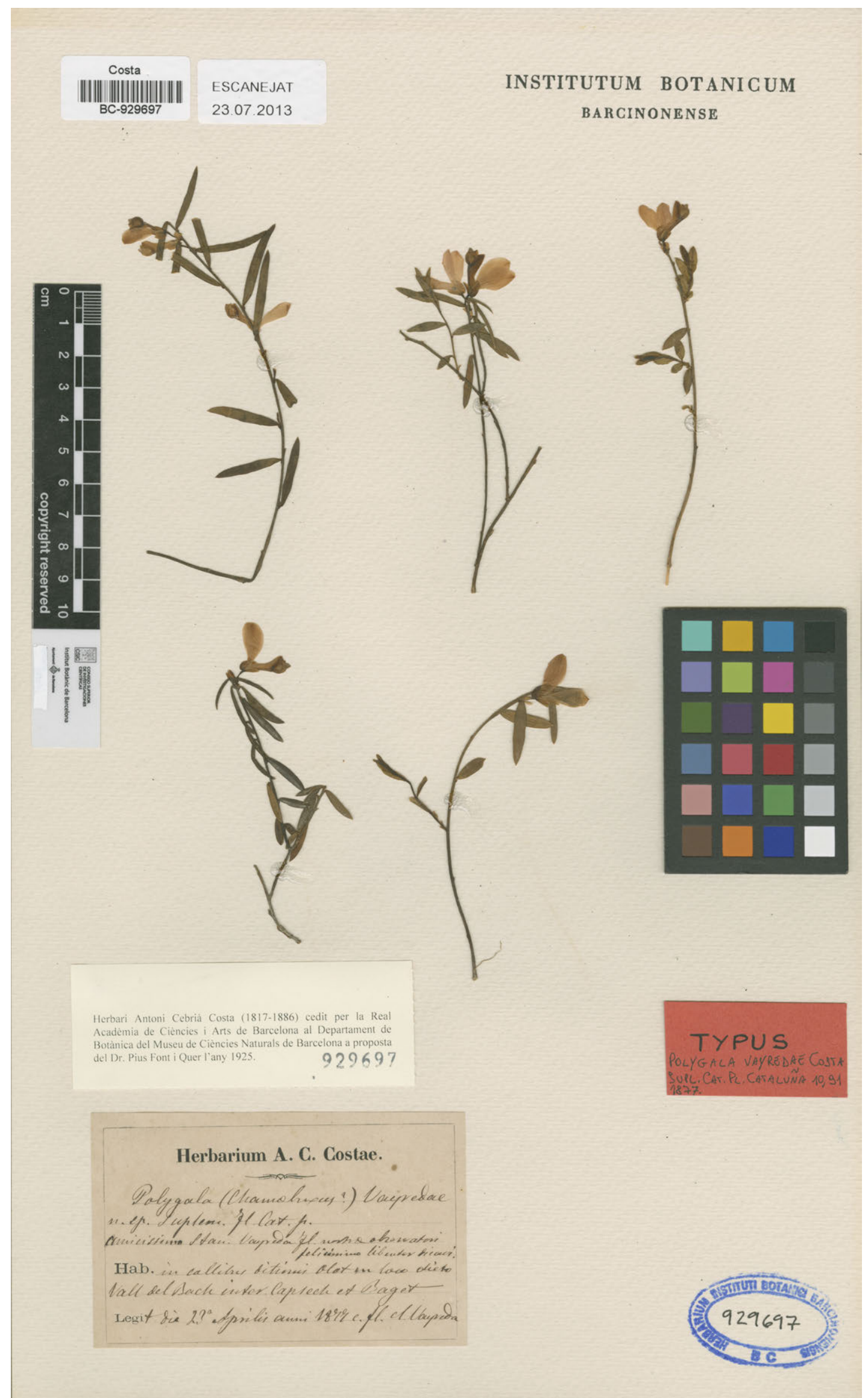

Fig. 3. Lectotype of Polygala vayredae Costa (BC-Costa 929697). 


\section{ACKNOWLEDGEMENTS}

We would like to express our gratitude to those who have helped us in carrying out this work, particularly to J.M. Camarasa, J.M. Montserrat, N. Nualart, L. Sáez, J.M. Tajadura, and J. Vallès, and thanks to the support of the project 2014SGR514.

\section{REFERENCES}

Bolòs, A. 1927. L’àrea de dispersió de la Polygala vayredae Costa. Ciència 2(12): 19-24.

Costa, A.C. 1877. Suplemento al Catálogo razonado de las plantas de Cataluña. Imprenta Barcelonesa. Barcelona.

Gavioli, L., Ibáñez, N. \& Soriano, I. 2013a. Estudios sobre el herbario Trèmols del Instituto Botánico de Barcelona. Boletín de la Asociación de Herbarios Ibero-Macaronésicos 14-15: 3-14.

Gavioli, L., Ibáñez, N. \& Soriano, I. 2013b. Aportació al coneixement de l'herbari Trèmols de l'Institut Botànic de Barcelona. Collectanea Botanica 32: 103-114. http://dx.doi.org/10.3989/collectbot.2013.v32.009

Lange, J.M.C. 1878. Diagnoses plantarum peninsulae Ibericae novarum, a variis collectoribus recentiori tempore lectarum. Videnskabelige meddelelser fra den Naturbistoriske Forening i Kjøbenhavn, ser. 3, 10: 222-241.

Lidén, M. 1986. Fumaria. L. In: Castroviejo, S. \& al. (eds.), Flora iberica 1: 447-467. CSIC, Madrid.

Loscos. F. 1876-1877. Tratado de Plantas de Aragón ed. 3. Establecimiento Tipográfico del Hospicio, Madrid. [Edición facsimilar. 1986. Instituto de Estudios Turolenses, Teruel.]

Luceño, M. 2008. Carex. In: Castroviejo, S. \& al. (eds.), Flora iberica 18: 109-250. CSIC, Madrid.

Muñoz Garmendia, F. \& González Bueno, A. (eds.). 2001. El epistolario de la colección Joaquín Loscos. In: Francisco Loscos y Bernal (1823-1886), un botánico aragonés 1: 45-406. Ibercaja, Real Sociedad Económica Aragonesa de Amigos del País y Real Jardín Botánico. CSIC, Madrid.

Pando, F. \& al. 1994-2010. Herbar: una aplicación de bases de datos para gestión de herbarios. Unidad de Coordinación de GBIF.ES, CSIC. http://www.gbif.es/herbar/herbar.php

Sáez, L., Aymerich, P. \& Blanché, C. (eds.). 2010. Llibre vermell de les plantes vasculars endèmiques $i$ amenaçades de Catalunya. Argania Editio, Barcelona.

Editores asociados: Ramón Morales y Alberto Herrero Recibido: 15-IV-2015 Aceptado: 23-XII-2015 